\title{
Communist Successor Party Adaptation in Candidate-Centered Systems: the Communist Party of Bohemia and Moravia and the Czech Social Democratic Party in the Czech Republic
}

\author{
Tatiana P. Rizova ${ }^{1}$ \\ ${ }^{1}$ Department of Government Christopher, Newport University \\ Correspondence: Tatiana P. Rizova, University P1. Newport News, VA 23606, USA. Tel: 1-757-594-7971. \\ E-mail: tatiana.rizova@cnu.edu
}

Received: February 22, 2012 Accepted: March 26, 2012 Online Published: June 1, 2012

doi:10.5539/jpl.v5n2p145 URL: http://dx.doi.org/10.5539/jpl.v5n2p145

\begin{abstract}
I compare the adaptation strategies of the Czech ex-communists to competitive elections upon the implosion of East European communism in 1989. In order to survive in a competitive electoral environment, parties that symbolize the communist legacy ought to refashion their internal organization and party programs; their leaders have to signal to their target electorate that they will jettison their predecessors' dictatorial practices and embrace democratic instruments. The direction and magnitude of these organizational and programmatic changes are dictated by the electoral goals of these parties' leadership and are shaped by important features of the electoral institutions such as ballot structure.
\end{abstract}

Keywords: czech republic, democratization, party organization, candidate selection, communist legacies

\section{Introduction}

The irreversible collapse of communism in Eastern and Central Europe ended scores of long-lived dictatorial regimes. The transition from totalitarianism to democracy in the region, however, did not immediately obliterate the political parties that helped install and run these repressive political regimes. As Soviet largesse dissipated, ex-communist party leaders in the satellite nations had to scramble resources that would help them vie for votes in quasi-competitive and competitive elections. It is hardly surprising that ex-communist parties had staying power beyond the moment of democratization. After all, their leaders had spent years accumulating economic resources, which helped these parties' successors distribute highly-coveted patronage in the first few post-communist elections (Kitschelt et al. 1999). Moreover, one could hardly expect that those who had benefited from the generosity of the communist welfare state would easily forfeit their social benefits and trade them for the untested promises of the newly-hatched democrats.

Macro-political explanations of the staying power of communist successor parties (CSPs) emphasize the effect of pre-communist and communist regime characteristics and legacies on their post-transition electoral fortunes (Ágh 1995; Kitschelt et al. 1999; Waller 1995). Though these explanations identify important conditions that can make or break a communist successor party, they oftentimes underplay the role of agency. This study focuses on the role of agency in molding the evolutionary path of communist successor parties. The leaders of successful CSPs have demonstrated that their parties select candidates who can win legislative seats in competitive elections. These leaders have also shown that they can craft appealing political messages, platforms, and programs.

Undeniably, part of the electoral success of ex-communist parties can be attributed to the failure of their adversaries to offer quick solutions to the economic crises that beset their countries in the aftermath of democratization. Ex-communist parties did reap an electoral bonus because some of their opponents were political neophytes and others incompetent managers. However, this inexperience and incompetence can hardly account for the successful adaptation of some communist successor parties. I argue that communist successor parties' performance in the electoral arena is contingent on their adaptation to the electoral rules that guide inter-party competition in their political systems. Electoral rules, I contend, affect the choices that ex-communist party leaders make in two fundamental ways. First, electoral rules shape the procedures that party leaders adopt 
for selecting candidates for elected posts. Second, electoral rules affect the profile of the candidates chosen to run on behalf of the party in electoral contests.

In this study, I focus on the effects of candidate-centered electoral systems on communist successor parties' adaptation mechanisms by examining legislative candidate selection and candidate profile in two Czech parties the Komunistická strana Čech a Moravy (KSČM or Communist Party of Bohemia and Moravia) and the Česká strana sociálně demokratická (ČSSD or Czech Social Democratic Party). While KSČM is the direct successor to the Komunistická strana Československa (KSČ or Czechoslovak Communist Party), ČSSD is a historic party, which was absorbed by KSČ in 1948. Even though ČSSD is not a communist successor party, it has been affected by the communist legacy, which makes for a meaningful comparison of the two parties' post-communist evolutionary paths. I propose the following hypotheses about the effects of candidate-centered systems on the legislative candidate selection procedures, candidate profile, and party programs of communist successor parties.

Hypothesis 1: Communist successor parties that compete in candidate-centered systems are likely to decentralize their procedure for legislative candidate selection.

Hypothesis 2: Communist successor parties that compete in candidate-centered systems are unlikely to nominate candidates with links to the communist regime.

Hypothesis 3: Communist successor parties whose leaders seek to appeal to a broad segment of the electorate are more likely to moderate their party programs than parties whose leaders turn their attention to their members and activists.

I derive the following predictions about the adaptation strategies of the Czech communist successor parties. First, CSPs that seek to appeal to broader segments of the electorate are more likely to adopt a decentralized legislative candidate selection procedure. Second, CSPs that aim to maximize their appeal amongst voters are less likely to select legislative candidates with links to the communist regime. Third, those CSPs whose goal it is to attract the general voter rather than party activists are more likely to moderate their party programs than retain their traditional ideological orientation.

\section{Electoral Rules and Patterns of Communist Successor Party Adaptation to Democratic Competition}

I categorize electoral systems into three groups - candidate-centered, party-centered, and hybrid. Candidate-centered electoral systems are those systems in which voters choose among candidates who compete individually as independents or under a party label as in plurality and majority runoff systems. The critical characteristic of the candidate-centered system is the higher importance of candidates' reputation relative to party reputation in affecting voters' decisions. Party-centered systems, on the other hand, are those in which voters choose among slates of candidates (party lists) as in closed-list proportional representation. Party reputation is relatively more important than candidate reputation in party-centered systems. In hybrid systems both candidate and party reputation weigh in voters' final decisions about which candidate or party list to support. In these systems voters get to choose their favorite candidate in single-seat districts and their favorite party list among several party lists.

\subsection{Determinants of Candidate Selection Methods}

There is a growing literature on the determinants of candidate selection methods in the scholarly work on political parties. Some authors have argued that candidate selection is affected by electoral system attributes (Epstein 1980; Hermens 1972). Plurality electoral systems in single-seat districts tend to be associated with decentralized candidate selection, whereas proportional representation systems tend to be associated with centralized candidate selection, the argument goes (Harmel \& Janda 1982). The argument is plausible for several reasons. In plurality elections voters cast a ballot for a candidate, which highlights the importance of the candidate's qualities and personal reputation as opposed to the party's reputation. One could argue that local constituencies, be they party members and activists or local party leaders, have better information about the voter appeal of individual candidates in their district than national leaders. If this is the case, then national party leaders will have an incentive to encourage the involvement of local constituencies in the process of candidate selection. National party leaders will most likely not abdicate full responsibility of candidate selection to local decision makers. They will reserve the right to veto candidates they find unsuitable or who are likely to break party ranks in the legislature. Local decision makers, on the other hand, will have an incentive to perform well in selecting viable candidates in candidate-centered competition, if they wish to participate in the nomination process in the future (Grzymała-Busse, 2002). The national party offices can always revoke the nomination authority they have granted local leaders, if the latter fail to choose viable candidates. Since local and national leaders engage in repeated interactions, local leaders will most likely recruit candidates with potential for 
political success. Candidate selection could be characterized by two procedures that involve single or multiple decision makers at different rungs of the party hierarchy - (a) the selection of nominees (nominations) and (b) the approval or rejection of the proposed nominees (vetoes). Characterizing the process of candidate selection as centralized or decentralized depends on which levels of the party hierarchy are involved in the two procedures. The most decentralized candidate selection procedure places control over both nominations and vetoes in the hands of local decision makers. The most centralized procedure, on the other hand, concentrates authority over nominations and vetoes in the national party headquarters.

Theories of legislative candidate selection focus on the process of candidate recruitment in the context of democratic competition. Communist parties are unlike any other party organization in that they were formed under undemocratic or pre-democratic conditions and were conceived as structural hierarchies. CSPs carry that organizational legacy forth and have to deal with its constraints when they compete with other political parties in quasi-democratic or democratic elections. Hence, CSPs cannot and should not be treated as a tabula rasa, for their leaders are accustomed to running organizations where power is shared by a handful of bigwigs. Now that these parties are campaigning to win constituents' votes in open electoral competition, however, the successor parties need to adjust to the incentives provided by their electoral environment. Candidate-centered competition, I argue, will provide incentives for the creation of a more decentralized party organization, whereas party-centered competition will be more conducive to the institution of a more centralized party structure. The candidate-centered nature of the Czech electoral system produces incentives to create and sustain more decentralized party structures, which will push Czech communist successor parties to dismantle their hierarchies by involving the lower levels of decision makers in candidate recruitment.

\subsection{Determinants of Candidate Profile}

Assuming that most voters cast a moral vote, and that they prefer democracy to communism, they will reject the candidacies of political aspirants who have a clear link to the communist past. (Note 1) Most collaborators with the state security apparatus, who happen to be responsible for abominable human rights violations, are shielded because their names appear only in classified documents. (Note 2) Political leaders, on the other hand, were almost always in the public eye. The advantage of competitive elections in post-authoritarian settings in general is that voters have the chance to cast a vote for candidates who had no ties to the authoritarian regime. Voters will now evaluate candidates based on candidates' personal political record and party affiliation. However, not all candidates with authoritarian links will be doomed. Membership in communist parties in communist regimes, for example, indicated political ambition rather than a serious commitment to the party ideology or involvement in its repressive apparatus. Even though some candidates may have served in higher ranking positions in the communist party hierarchy, voters may still give them a chance to participate in democratic politics.

The weight of communist legacies is not borne equally by all aspirants with ties to the communist regime. Having established a record of dissident or reformist activities inside the communist party under communism or during democratization, for example, is one possible strategy of 'cleansing' one's reputation. In fact, individuals with a strong dissident record may be in a better position to present themselves as democrats than any newcomer without a political record. Dissident activity inside the communist party ranks, one may argue, was probably the only feasible strategy of affecting policies under communism. Thus, it is important to understand the subtle nature of the communist link and its potential consequences for the reputation of a candidate and the party he represents. I expect that, ceteris paribus, candidates with links to the communist party are less likely to be elected than candidates without such links. (Note 3) Communist successor parties that compete under candidate-centered electoral rules will have the incentive to select 'clean' candidates rather than candidates with communist links. (Note 4)

I discuss the adaptation of successor parties in candidate-centered systems by comparing the strategies of the Communist Party of Bohemia and Moravia as the main successor to the Communist Party of Czechoslovakia and the Czech Social Democratic Party as a historic party. I explore the effects of the communist legacy on these political parties and how it has interacted with the incentives of the electoral system in shaping their electoral strategies in three consecutive parliamentary elections - 1990, 1992, and 1996. The first two elections preceded the Velvet Divorce between the Czech Republic and Slovakia, whereas the third election followed it. I focus on parliamentary elections because the Czech Republic is a parliamentary system with an indirectly elected president who has few legislative prerogatives. Parliamentary elections, therefore, are the mechanism of selecting both legislators and members of the executive. 


\subsection{Testing the Effects of Electoral Systems on Communist Successor Party Adaptation Strategies}

For those CSPs whose leaders wish to appeal to broader segments of the electorate the three-pronged adaptation strategy to candidate-centered competition will contain the following elements: (a) decentralized legislative candidate selection, (b) distancing the party from its communist legacy by choosing few or no candidates with links to the communist regime, and (c) moderation of the party program on salient economic and political issues.

Electoral contests in the Czech open-list proportional representation (PR) system are personalized and successor parties are more likely to choose appealing candidates by delegating candidate nominations to local party branches. This candidate selection strategy, however, could be deleterious to a successor or any other party if the preferences of the selectors (people who choose legislative candidates) significantly differ from the preferences of the target electorate.

The communist successor party leadership will likely choose few candidates with links to the communist regime. This prediction will most likely not hold in systems where politicians rely exclusively on patronage to attract votes. In such systems voters rarely cast a moral vote based on their assessment of candidates' reputation. Some voters are much more likely to vote for a candidate with communist links because he is well-connected and can provide money, food, jobs, university placements, and other valuable benefits. Politicians in the Czech system probably rely on patronage to some extent, but most Czech politicians do not get elected based on their capacity to procure direct benefits to their voters. Many voters are likely to cast moral votes, but even this does not guarantee that a voter would prefer a clean candidate to a candidate with links to the communist regime. Post-communist elections have provided at least a few examples in which voters have knowingly supported the candidacies of politicians with links to communism because opposition parties were unable to put forward equally qualified and charismatic candidates. Personalization also provides incentives for the selection of candidates with ties to their electoral districts.

CSPs in the Czech system will have the incentive to significantly moderate their electoral messages, if they wish to participate in the executive. The extent of moderation depends on the electoral goal the party leadership has set. If the party merely seeks some parliamentary representation, it may not have to moderate its messages, particularly if (a) its group of core supporters is large enough and (b) if the geographic distribution of its core supporters allows the party to overcome electoral thresholds easily. If the party seeks to participate in a governing coalition, overcoming the electoral threshold will not be sufficient. It may have to moderate its messages more in order to appeal to a larger constituency. Without some programmatic moderation successor parties are also unlikely to be viewed as attractive coalition partners in the formation of electoral or government coalitions.

I show that the Communist Party of Bohemia and Moravia has indeed decentralized its candidate selection. However, my findings indicate that KSČM did not decentralize candidate nominations in order to choose more appealing candidates; its goal was to cater to its core supporters who had demanded more involvement in decision making. While activists were content with their newly-won prerogative, voters were hardly pleased with the menu of candidates they were offered at the elections. The party did not attract many votes beyond those of communist zealots.

After initial attempts to soften the communist image of the party floundered, its reformist leaders relinquished power to orthodox communists. The power shift resulted in the adoption of a traditional communist program, which caught the fancy of constituents with radical communist views. Czech communists refused to transform their organization into a modern social democratic party in the likeness of other ex-communist parties in Eastern and Central Europe. Their devotion to communist principles, however, has not compromised their capacity to influence legislation in the Czech parliament. While the party has had limited coalition potential and has never participated in a governing coalition, it held strong blackmail potential (Sartori, 2005) when its archrival - the Czech Social Democratic Party - was in charge of the government. (Note 5)

Rather than being considered the least reformed and the least successful ex-communist party in the former Soviet Bloc, however, the Communist Party of Bohemia and Moravia should probably be viewed as the most successful orthodox communist party among the parties that survived democratization. No other ex-communist party in the region whose label still contains 'communist' has cinched between $10 \%$ and $18 \%$ of the popular vote in each parliamentary election since 1990. The Czech ex-communists did adopt an optimal strategy of adaptation to the new electoral conditions given the electoral goals their leaders had set - to cater to the demands of their members who revered communist ideals and values.

The most successful left-wing party in the Czech Republic is the Social Democratic Party. After failing to win seats in the 1990 election and hobbling into parliament in the 1992 election, ČSSD became a major political 
contender and formed governments in 1998 and 2002. The Social Democrats drew the attention and votes of the social democratic constituency, the votes the Communists had forgone by refusing to moderate their electoral programs. ČSSD did not merely capitalize on the Communists' inability to attract the social democratic voters. Its success was also partly due to its leaders' judicious choices of candidates for legislative office. The Social Democrats relied on vital feedback from local offices in choosing candidates. Whereas the local Communist activists were much more extreme in their political views than most of the social democratic electorate, Social Democratic activists were moderate. Having extricated themselves from their subordination to the Communist Party of Czechoslovakia, the Social Democrats successfully built up their local organizations, overcame ideological schisms, and severed their links to KSČ. Within six years of the transition the Social Democrats had come out of obscurity to claim significant political turf.

\section{Successor and Historic Parties in the Czech Republic}

During the consolidation of totalitarianism in Czechoslovakia (1948-49) all political parties were absorbed by the Czechoslovak National Front, which was organized on the principle of democratic centralism. (Note 6) The fate of rival political opposition movements and associations was no different from that of the opposition in other corners of the Soviet totalitarian empire. By 1945, the National Front had successfully co-opted 18 organizations including civic organizations such as the Union of Fire Brigades, the Association of Philatelists, and the Czechoslovak Fishing Union (Brokl \& Mansfeldová, 1996). The leaders of three larger organizations aspired to re-enter politics after the communist meltdown. The Czechoslovak Communist Party, the only legitimate communist successor party in Czechoslovakia, was the best organized of the three.

The mainstay of the National Front was, of course, the Communist Party of Czechoslovakia, which was founded in 1921 as an anti-system and anti-regime party. Its organizers found inspiration in Marxist intellectual tradition and the Bolshevik Revolution. The party was dissolved and worked clandestinely between 1938 and 1945. Its fortunes improved after World War II, and with Soviet support, it helped institute communism in Czechoslovakia.

The Česká strana socialistická (ČSS or Czech Socialist Party), founded in 1898, was forced into co-existence with the Communist Party during the communists' forty-year-long rule. (Note 7) The Socialists sought to disassociate themselves from the National Front immediately after transition; their first step toward cutting their ties with the communists was their open financial and moral support of the opposition movement Občanské forum (OF or Civic Forum) in the 1989 elections. ČSS won no seats in 1990, but won some seats after it joined two smaller parties to form the Liberálně sociálni unie (LSU or Liberal Social Union). The party boasted the second largest membership after KSČM, but its ideological positions were more moderate than those of KSČM, and was therefore considered a more attractive coalition partner than the Communists (Novák, 2003).

The Czech Social Democratic Party was the only historic party that had played an active role in Czechoslovak politics before the country succumbed to totalitarianism in 1945. It was founded in 1878, but was absorbed by the National Front (which was subservient to the Czechoslovak Communist Party) in 1948. It formally split from the Communist Party after the communist collapse and became the most successful social democratic party in the country. Though some of its leaders had been co-opted by the National Front, many had remained politically active in exile. Their activity would help the resurgence of the party in the post-communist era. The ČSSD party leaders could not merely rely on portraying themselves as victims of Czechoslovak communism; they had to establish a credible reputation as democrats to win people's support. (Note 8) Even though the Social Democrats did not win any seats in the 1990 parliamentary elections, many parliamentarians who considered themselves social democrats, and later joined ČSSD, were active in the Civic Forum within the reform communist club Obroda (Revival). (Note 9) ČSSD included moderate leftist leaders who had been politically active in numerous organizations. Some had been ČSSD leaders living in exile, others had deserted KSČM ranks, and a third group had split from Civic Forum.

The Communists and the Social Democrats had a history of rivalry long before the communist coup of 1948 . The members of the Social Democratic Party had been the first target of the Communist Party in the years after World War II. In most cases communist apparatchiks did not have to force members of rival organizations to join their ranks. Party membership (in any political party) had been a valuable asset to anyone who sought a career in the civil service since the 19th century (Suda, 1980). After the Communist Party assumed political monopoly, aspiring civil servants were compelled to become members of the Communist Party. On some occasions the Communist Party resorted to not so subtle hints - 'many hesitant followers of the non-Communist parties suddenly found on their desks application forms for CPCS (Communist Party of Czechoslovakia) membership, ready to sign' (Suda, 1980). The Czechoslovak Communists 'invited' each member of the Social 
Democratic Party to follow his conscience in deciding whether to join the National Front. Personal invitations were supposed to signal the natural fusion of the two party organizations. In reality members of other parties could only decline the invitation at the risk of losing their liberty or lives. Historical accounts of the creation of the National Front have shown that KSČ coerced its political opponents to join it or else perish. Yet, former adversaries of the communists still had to prove that they had not been tarnished by the communist legacy upon the dissolution of the National Front. Proving that they had not been responsible for economic and political oppression, showing the voters that they were not the masterminds of catastrophic economic plans and abominable human rights violations was no trivial task. The association of the Social Democrats with the communist regime proved to be their Achilles' heel and a fact they had to reckon with throughout the 1990s (Pšeja, 2005).

\section{Adaptation Strategies of the Czech Successor Parties - Electoral System Attributes and Expected Consequences on Candidate Selection, Candidate Profile, and Ideological Adaptation}

\subsection{Electoral System Attributes and Expected Effects on CSP Adaptation Strategies}

The Czech Republic has a bicameral parliament, which has allowed ex-communist leaders to re-enter national politics by running for an elected post in either chamber. The Czech electoral legislation in the lower chamber allows voters to cast a ballot for a list of candidates competing on behalf of a political party or an electoral coalition. In addition to choosing a party list, voters can also express their preference for up to four candidates on the list. (Note 10) Filip (2003) has noted that a majority of the Czechoslovak voters exercised their right to a personal vote for select candidates on their preferred party list in the 1990 election to the Federal Assembly. Preference votes are taken into consideration in the event at least $10 \%$ of the voters who chose a party list in a given electoral district used their preference votes. It is possible, then, that preference votes would be taken into consideration for one party list and not for another (or in one electoral district for the same party and not another) According to the 1990 electoral legislation, candidates who gained at least $50 \%$ of the preference votes could advance to the top of the list in their electoral districts (Article 43, paragraph 3). (Note 11) If an insufficient number of voters had used their preference votes, then candidates would have been elected according to the list rank given to them on their party list. In the event two candidates obtained an equal number of votes, then the candidate whose party rank was higher advanced on the list. The rule about counting preference votes changed for the 1992 National Council elections. The new rule stipulated that a candidate needed $10 \%$, as opposed to $50 \%$, of all votes cast for that list in an electoral district to advance to the top of the list (Article 50, paragraph 4). (Note 12) If more than one candidate overcame the $10 \%$ threshold, then the list would be re-ranked according to the number of preference votes received by the candidates. (Note 13) Even though voters influence the final ranking of list candidates, party leaders' evaluation of candidates' talents and potential to win votes for the list are important in determining rankings. Political parties that consistently fail to place appealing candidates at the top of their lists are not likely to perform well in parliamentary elections.

Among the successful parties in the 1992 election, voters' preferences only determined the rank order of the candidates who had already received a safe spot on their party list. Only two of the candidates of the Czech Social Democratic Party, for example, won legislative seats with the help of voters' personal votes. They had received low party rankings and would not have won a seat under a closed-list proportional representation system (assuming that voters' behavior stayed the same in a closed-list proportional representation system). Thus, voters' preferences did not truly 'save' any candidates who had received a poor party ranking. All voters had accomplished was determine the rank order of candidates who would have won a parliamentary seat with or without the loyalty of their political supporters. One of the most persistent grievances of MPs themselves is the party-orientation of the electoral system. In a 1992 survey nearly one-fifth of all respondents (all MPs) mentioned that the system favors political parties and gives them too much leverage in sealing the electoral fate of their candidates (Kopecký, 2001).

The theory presented here predicts that candidate selection in an open-list system with some degree of personalized competition will be decentralized. (Note 14) A closed-list system, on the other hand, will provide weaker incentives for decentralization. There may be variations in the degree of overlap of candidates' initial and final rankings across districts and across party lists. The overlap of candidates' initial and final rankings has several alternative interpretations. First, it may imply that voters' and leaders' preferences over candidates are alike. Second, voters may merely be imitating leaders in their preferences over candidates (or they are simply rational in sanctioning the candidate slate that has already been given to them). Third, leaders may have correctly guessed voters' preferences over candidates. Thus, the coincidence of initial and final rankings does not necessarily imply that voters' choices have been limited, and the system produces outcomes equivalent to results in a closed-list proportional representation system. To my knowledge, there are no pre or post-election surveys, 
in which Czech voters have been asked whether and why they planned to cast (or did cast) preference votes for certain candidates. The third interpretation seems to be the one consistent with my theory. Those parties that rely on decentralized selection mechanisms are more likely to place those candidates in safe spots who closely match voters' preferences. If most voters used their personal votes (or if casting personal votes were mandatory), then a divergence of initial and final list rankings would indicate divergence of voters' and leaders' preferences over candidates. (Note 15)

KSČM, ČSS, and ČSSD have also placed candidates in senatorial races. KSČM has supported the senatorial candidacies of some former representatives of the top tier of the communist party hierarchy. Elections to fill seats in the Czech Senate are held in single-seat districts and have been based on a majority runoff rule. (Note 16) Senatorial candidates in each of the 81 districts compete in two rounds unless a majority winner emerges in the first round of elections (Filip, 2003). This is an example of a candidate-centered system, in which voters cast a vote for a candidate rather than a party list. Though personal reputation and qualities have substantial weight in affecting voters' choices, most senatorial candidates tend to be affiliated and supported by parties. Assuming that aspirants place equal value on lower and upper-chamber seats, I expect to observe fewer candidates with communist links in senatorial races than parliamentary races in the Czech Republic. (Note 17) Personalized races place candidates in the spotlight, and unless the pre-democratic political record of the candidate is commendable, he stands little chance of electoral success. Though the party list vote in lower-chamber elections tends to be personalized, it is still possible for some ex-communist candidates to find safe spots on the lists. Assuming that voters cast a moral vote and prefer candidates without links to the ex-communist party, it will be harder for ex-communist candidates with tainted reputation to obtain ballot access in personalized contests.

\subsection{Candidate Selection Procedures in the Communist Party of Bohemia and Moravia and the Czech Social Democratic Party}

How have ex-communists responded to the incentives of the Czech electoral system? Have they decentralized candidate selection in an attempt to select candidates who are likely to boost party support or do they still observe the old communist tradition of centralized candidate recruitment?

The candidate recruitment procedures of the Czechoslovak Communist Party were centralized in the founding elections in 1990 (Grzymała-Busse, 2002; Hanley, 2002; Van Biezen, 2003). (Note 18) The local party offices had the authority to nominate candidates to the party lists. Šimíček (2003) reports that most political parties in the Czech Republic preferred to nominate candidates who had ties to their electoral district. In the absence of general legislation on candidate selection, this unwritten principle has been followed by the majority of the political parties which contested elections in the country between 1990 and 1996. KSČM leaders have tended to follow this rule. Once candidate names have been submitted by the local organizations to the Central Committee (CC), the CC makes final decisions about who would head the party lists and candidate rankings.

The internal democracy established through the nomination and candidate approval system in the KSČM in 1990 was illusory at first. (Note 19) The process was fully controlled by the national headquarters in Prague, and local officers had to observe strict guidelines established by the Central Committee. Even though the members at the local level had nomination powers, they had to choose candidates who, in the eyes of the top leaders, met the party guidelines. The final approval rested with the national headquarters, and the decisions of the Central Committee were not subject to appeal. (Note 20)

In 1992 KSČM became the first Czechoslovak party to experiment with party primaries, which allowed registered members to select legislative candidates for the 1992 parliamentary elections. My general expectation is that unless there is significant disparity between the preferences of the selectors and the target constituency decentralization is an electoral advantage. Delegation to decision makers at the electoral district level should, at least in principle, allow parties to choose more appealing candidates. The experience of the Czech ex-communists, however, demonstrates that when the preferences of the selectors and the broader electorate are at odds, decentralization is not necessarily propitious. The predicament of the KSČM was complicated by the absence of a central vetting mechanism, which would have allowed the party bosses in the national headquarters to veto nomination decisions that were made locally. The primaries simply allowed orthodox communist activists in local branches to pull their weight in candidate selection decisions. (Note 21) Delegating to the local level while retaining veto authority would have been a sounder candidate selection strategy. Still, it is doubtful that it would have contributed to significant electoral success given the successor party's refusal to shed its traditional Marxist slogans and appeals. Grzymała-Busse (2002) has found that the 1992 electoral outcomes of KSČM were poorest in those districts where local members had rallied most actively to help organize the electoral campaign. 
The party did well above its national average in Tachov, Louny, Most, and Kutná Hora - where its organizations had been labeled "inactive and useless." On the other hand, where it had had earlier identified strong local organizations, as in Liberec, České Budejovice, and Hradec Karlové, it had poor electoral results. The one place where both organizations and electoral results were poor was Prague.

The interests of activists and the leaders in this case were not perfectly aligned. While the activists sought to preserve the ideological purity and communist image of the party, the leaders were hoping to win more votes, at least a sufficient number of votes to secure their own parliamentary seats.

Why did the KSČM not use its advantage to attract the social democratic vote, and allowed the ČSSD to do it? One of the arguments advanced in the communist successor party literature is that most of the active members of the KSČM were orthodox Marxists and they pushed the party on a classical Marxist ideological trajectory. Even though there were some early attempts to resuscitate the party, they were unsuccessful because it was dominated by groups who opposed its decommunization and its transformation into a solid social democratic force (Grzymała-Busse, 2002). After the abortive reform of KSČM and its failure to formulate a social democratic agenda, the social democratic constituency turned to the only other viable alternative - the Czech Social Democratic Party. The Social Democrats could have been accused of complicity with the communist dictatorship, yet they managed to convince voters that their party was the victim rather than the perpetrator of repressive acts.

The Czech Social Democrats were viewed as trouble-makers during communism, which prompted discussions about their status in 1968. Social Democratic leaders sought to establish independent party branches, but orthodox communists saw their aspiration as a threat to communism. Communists were in no hurry to sow the seeds of their own destruction. 'The communists also feared that if their party were exposed to competition from another party of the working class, and one untainted by the sins of the recent past, the CPCS [Communist Party of Czechoslovakia] would become a rump of diehard Stalinists and apparatchiks', writes Crampton (2003).

In addition to adopting a moderate social democratic platform, the Czech Social Democrats introduced a decentralized mechanism for selecting candidates to the Czech Parliament. (Note 22) In the first couple of years, when the ČSSD was not very popular and could not boast large parliamentary representation, the selection procedure was centralized. The high-ranking party leaders were responsible both for the nominations and the approval of all candidates who ran in legislative elections. The average district magnitude is quite large in the Czech system (14 seats per district), and there are only seven electoral districts. The voters of the ČSSD have tended to use their preference votes, but these votes rarely lead to a substantially different ranking of the individual candidates on the party lists. Most of the changes occur at the very top of the list, among the top five candidates, and this tendency has persisted over time. It was not until later, following the 1992 elections, that the Social Democrats decentralized candidate recruitment procedures.

\subsection{Profile of the Legislative Candidates of the Communist Party of Bohemia and Moravia and the Czech Social Democratic Party}

My investigation of the first-tier party officials revealed an interesting outcome. (Note 22) There was only one member of the Politburo or the Central Committee who ran as a candidate of the Ćeskoslovenská sociálni demokracie (ČSD or Czechoslovak Social Democracy) in the 1990 parliamentary elections. (Note 23) He was ranked at number 13 on the Jihomoravský regional list, received 540 personal votes, and was not elected to parliament just like the other candidates of the party. No Politburo or Central Committee member ran in the lower house elections as a KSČM candidate between 1990 and 1996. Only three top communist officials ran in the Senate race between 1990 and 1996. Two of them - Ladislav Adamec and Miroslav Štěpán - ran under the KSČM and the restored KSČ label respectively. Adamec ran in all three elections, whereas Štěpán ran only in the 1996 elections. Adamec secured a senatorial seat by running on the KSČM list in the Severomoravský region in the 1990 and 1992 elections, whereas Štěpán was unable to win a seat. (Note 24) Adamec was the top-ranking member of the Presidium of the Communist Party of Czechoslovakia in 1989. Štěpán had also been a member of the Presidium. The third top communist leader - Vasil Mohorita - ran under the label of the Strana Demokratické Levice (SDL or Party of the Democratic Left) in the 1996 Senate elections and did not win a seat. He had been a member of the Central Committee Secretariat till 1989. Note that this outcome contradicts my expectation that there would be fewer candidates with communist links in the contest for senatorial seats. The decision of the KSČM to place three well-known Politburo chiefs in senate races was probably dictated by the personal reputation each of them had established during the transition process. The respectability of high-ranking party functionaries partly depended on their activities and the position they had held during the 1968 Prague Spring and at the threshold of the democratic changes. Any politician, who had been complicit in the suppression of dissidents in 1968, stood a paltry chance of being nominated for a seat in either legislative chamber. Ladislav 
Adamec, who was the ranking leader of the Czechoslovak Communist Party in 1989, had demonstrated his commitment to democratization by refusing to authorize the suppression of the protesters in the squares of Prague and Bratislava in 1989. There would be no Tiananmen Square massacre in Czechoslovakia while he stood at the helm. At a meeting in late 1989, as the crowds were swelling the streets of the republic, Adamec made a historic speech in which he acknowledged that the Czechoslovak Communist Party could hardly boast a perfect political record. 'To look truth in the eye means to realize that the loss of political trust as a result of mistakes in leadership must be paid for. And there have been many in the last twenty years, and not small ones. I am convinced, however, that we need not pay too high a price, if we can manage to mobilize the Party', said Adamec. (Note 25) Adamec had also built the reputation of a communist pragmatist and reformer after proposing economic reform in the early 1980s (Hanley, 2002). There had been little support for reform in the overwhelmingly conservative Czechoslovak Communist Party, and none of the proposed reforms had come to fruition.

It is hardly surprising that Miroslav Štěpán's attempt to win a senatorial seat was futile. He was the first former Politburo official to be tried for his involvement in the attempted suppression of a mass demonstration in Prague in 1989. In 1995, he created a radical Marxist party named Party of the Czechoslovak Communists (which later took on the name Czechoslovak Communist Party). To date, none of the party's candidates have won any legislative seats.

The candidate lists of the Czech Social Democratic Party did not contain the names of any first-tier politicians (with one exception in 1990). The lists of the KSČM had relatively few first-tier former communist leaders. This outcome could be attributed partly to the stricter lustration laws and to the more open nature of the electoral process through the personalization of the vote of the Czech open-list proportional representation system. Comparative studies of elite recruitment patterns in Central Europe have shown that between 1989 and 1998 there was a smaller percentage of MPs who served as Communist Party officials in the Czech Republic (7.8\%) than in either Hungary (9\%) or Poland (12.5\%) (Hanley et al., 1998). It is difficult to evaluate the relative importance of the open-list system and the effectiveness of lustration legislation in reducing the number of candidates with communist links. Both factors played a role, and most likely the visibility of candidates in the open-list system increased the effectiveness of the lustration legislation. (Note 26) Another factor, which must have helped expose collaborators with the communist regime, was the availability of information about collaboration with the police apparatus much before the 1989 transition. In Bulgaria, for example, reliable information about collaboration with the communist repressive machine did not surface until 2006; in contrast, such information was already being collected in the Czech Republic in the late 1960s. 'In their search for the truth the Czechoslovak intelligentsia in the early months of 1968 unearthed and made public shocking details of the communist past. In their demand for explanation of these events the enquirers produced what was a virtual inventory of the Soviet system as applied in Czechoslovakia', wrote Crampton (2003).

The transitional period is a turning point not only for the opposition leaders, but also for the former communist party officials. The actions of individual politicians during single party rule, their political stances and involvement in quenching popular uprisings during the dictatorship, and their positions during transitional events can help turn them into heroes or villains. The story of Adamec and Štěpán is an illustration of how one became a hero and the other a villain in the eyes of the Czech voters.

\subsection{Ideological Adaptation of the Communist Party of Bohemia and Moravia and the Czech Social Democratic Party}

There was potential for ideological moderation of the Communist Party of Bohemia and Moravia between 1990 and the Velvet Divorce of 1993. At that time the party was the arena of bitter internal conflicts over ideological and organizational issues and leadership. The intra-party factions, which had formed prior to the 1990 Congress, dissented on the party's post-transition path. Orthodox communists wanted to keep the party ideology as close as possible to its original communist principles. The Democratic Forum of the Communists (DFK) called for some decentralization and internal democratization (Grzymała-Busse, 2002; Pšeja, 2005). The Democratic Left attempted to push the party in a social democratic direction. Ideological conflict centered on the tension between preserving pre-transition party ideology and adopting social democratic principles. In essence, this was a choice between catering to members' interests most of whom were elderly orthodox communists and appealing to the larger social democratic constituency. Catering to members' interests would entail preserving the party name and keeping its traditional communist image and messages. Appealing to the larger social democratic constituency would imply following into the footsteps of other ex-communist parties in Europe, changing the party name and burnishing the party image and ideology by veering away from the far left toward the center. Turning toward members also meant that the party could rely on the steady electoral support of its core members and activists, 
which would help it overcome the 5\% threshold for winning parliamentary seats. The party would not, however, be well-positioned to earn enough votes and seats to win ministerial portfolios. The other path would have meant losing the support of the staunchest party members, the diehard communists, in the hope of winning the votes of the more moderate social democratic constituency. In the first scenario, then, the party would focus on a slim section of the Czech electorate and effectively become an anti-systemic party, unless the electorate swung far left on the left-right axis. In the second scenario, on the other hand, it had the potential to become a major political player and participate in the executive like the Bulgarian and the Hungarian Socialists. It was not clear which path KSČM would take until the internal conflict between the proponents of the two paths was resolved in 1993.

Opinion surveys have shown the presence of strong socialist/social democratic values among Czech and Slovak voters. Eighty-one \% of the people surveyed in the Czech Republic supported a state-run agricultural sector, $69 \%$ approved of the idea of state-provided housing, and $73 \%$ thought that the state should set prices for basic goods and services (Miller, White \& Heywood, 1998). Fifty-three \% agreed with the statement that 'restricting the gap between rich and poor is more important than the freedom to make money' (Miller, White \& Heywood, 1998). Sixty-two \% supported the idea of state-provided welfare (Miller, White \& Heywood, 1998). Sixty-eight \% of Czech people claimed that social democracy was the best model economy for their country. Forty $\%$ agreed with the statement that 'it is more important to guarantee that no one is in need (in their society) than to allow people freedom to pursue life's goals'. (Note 27)

At the same time, people's sentiments against the restitution of a communist regime were strong and unambiguous. Only $29 \%$ of those surveyed stated that they had believed in communist ideals. Merely $15 \%$ said that they still believed in communist ideals (Miller, White \& Heywood, 1998). Forty-six \% cited that the oppression of human rights was the worst feature of communism, while only $15 \%$ stated that economic stagnation was its worst feature (Miller, White \& Heywood, 1998). Thirty-two \% of the people surveyed stated that the period under Tomáš Masaryk's presidency (1920-1935) was the best time of the $20^{\text {th }}$ century; $17 \%$ thought that the political revival of the Prague Spring in 1968 was the best time, and $40 \%$ stated that the post-communist period was the best time. Only seven $\%$ of the people cited their preference for the period when Brezhnev was at the helm of the Communist Party of the Soviet Union (Miller, White \& Heywood, 1998). There was also wide popular support for settling accounts with those who had committed human rights violations under communism. Fifty-two \% of the people thought that the secret police files should be made public, and $81 \%$ stated that those responsible for past injustices should be punished (Miller, White \& Heywood, 1998). All of these surveys were conducted between 1990 and 1993, so it is quite clear that most Czech citizens rejected communism and acknowledged the flaws of the communist system in this time period. It is also evident that though they repudiated communism, Czech people, just like most others who had lived under communism, were not prepared to forgo the economic benefits and job security the communist governments had provided.

Clearly, there was a large social democratic constituency in the Czech Republic whose votes were up for grabs during the first few democratic elections. These elections happened to be the most opportune moment for ideological change. KSČ leaders paid lip service to superficial change during their Extraordinary Congress. The congressional resolution "included a blanket rejection of the doctrines of the normalization period; an apology for wrongdoings of the Communist Party since 1948, an acceptance of the loss of its "leading role"; general endorsements of the rule of law of a "socialist market," human rights and democracy and a commitment to become a modern political party' (Hanley, 2002). That commitment to change, however, was half-hearted. Some party leaders even glorified the communist years as 'one of the greatest periods of social and economic growth' (KSČM electoral program, 1996).

The more progressive party leadership had pressed conservative leaders such as Miloš Jakeš and Miroslav Štěpán to resign, which helped improve the party reputation slightly. The party was building momentum for reform under Jiř́i Svoboda's leadership. A prolific and progressive film-maker and intellectual, Svoboda lacked sufficient political experience. In spite of being a newcomer in Czech politics, he came on board KSČM's sinking ship armed with enthusiasm and reformist ideas. Svoboda's goal was 'to make it [KSČM] the basis of a solid, well-organized Left acceptable to a large part of Czech society by salvaging the democratic and progressive aspects of its communist tradition and distancing the party from its totalitarian past. This would entail dropping the word "communist" for the label "democratic socialist" or "Radical Left"" (Hanley, 2002).

The momentum for reform quickly dissipated and Svoboda's reform efforts proved fruitless. He was unable to stand his ideological ground in the face of a Central Committee dominated by old party hacks (48 of 109 members). 'In relying on the party's membership, and giving it such influence within the party, the Czech leaders effectively became the hostages of an army of communist stalwarts', argues Grzymała-Busse (2002). By the time the ideological squabbles in the KSČM were over, the Social Democrats were beginning to receive 
stronger support among social democratic constituents. By 1996 ČSSD had already become the most influential party expressing the views and aspirations of the large mass of people with social democratic values.

One might argue that internal democratization granted members too much decision-making authority both in candidate selection and ideological formulation, which eventually sabotaged the party's electoral performance. It seems that decentralization in itself did not hinder reform; rather, what prevented early reform was empowering members whose preferences and vision about party reform did not match the preferences of the social democratic voters. Had the party members been as moderate in their ideas about economic and political development as the social democratic voters, KSČM would have reformed more easily. It would have become a strong social democratic party, and perhaps ČSSD would not have stood a chance in the face of a reformed KSČM. What certainly helped the Social Democrats boost their popularity among the social democratic voters was the lack of competition from other political parties in the center-left of the economic dimension. By failing to appeal to the social democratic constituency, the former communists gave the Social Democrats a golden opportunity to cultivate the social democrats' loyalty (Grzymała-Busse, 2002). The Czech ex-communists, then, settled for the votes of their most loyal fans - the orthodox communists who would support a Marxist KSČM unconditionally. KSČM leaders chose to nurture the party's loyal electorate instead of seeking new bases of support among more moderate social democratic voters.

Table 1. Dominant Themes in the Political Programs of KSČM and ČSSD (1992-1998)

\begin{tabular}{|c|c|c|c|c|c|c|}
\hline \multirow{2}{*}{$\begin{array}{l}\text { Ideological } \\
\text { position } \\
\text { Year }\end{array}$} & \multicolumn{2}{|c|}{$\begin{array}{l}\text { Market } \quad \text { Economy }(+ \\
\text { approval/-disapproval) }\end{array}$} & \multicolumn{2}{|c|}{ European Union Integration } & \multicolumn{2}{|c|}{ Past (Property Restitution) } \\
\hline & KSČM & ČSSD & KSČM & ČSSD & KSČM & ČSSD \\
\hline 1992 & 0.65 & 1.07 & 0.90 & 3.75 & -0.49 & -0.8 \\
\hline 1996 & 1.80 & 2.14 & 0.49 & 3.70 & -0.73 & 0.39 \\
\hline 1998 & 2.18 & 1.71 & 0.48 & 5.39 & -0.17 & 0.13 \\
\hline
\end{tabular}

Note: The numbers in the cells indicate the $\%$ of the party program dedicated to a given issue. A positive sign means endorsement of a market economy, European integration or property restitution. A negative sign means negative positions on these issues.

Source: Klingemann, H. et al. (eds) (2006) Mapping Policy Preferences II: Estimates for Parties, Electors, and Governments in Eastern Europe, European Union, and OECD 1990-2003 (Oxford, Oxford University Press).

The Czech Social Democrats were not immune to internal conflicts. Two of their leaders - Rudolf Battěk and Jiři Horák - had won the loyalty of party supporters. The debate over the party leadership was resolved in 1990 when Battěk's group left and became part of the opposition Civic Forum, which won the founding elections in Czechoslovakia. ČSSD did not win any parliamentary seats in 1990, won only a few in 1992, but gradually strengthened itself and by 1996 had become the most respected social democratic force in the Czech Republic. Table 1 displays some of the dominant themes in the KSČM and ČSSD party programs in the 1992, 1996, and 1998 parliamentary elections. The numbers indicate the positions (positive or negative) and the importance of each issue in the party program in these elections. I focus on three issues - approval or disapproval of a market economy, support or opposition to European Union integration, and support or opposition to property restitution to the victims of nationalization under communism. ČSSD paid much more attention to the introduction of a market economy in the country than the KSČM. Both parties supported EU integration, but ČSSD allocated much more space to endorsing EU membership in its program than did KSČM. The last column in the table shows that KSČM was haunted by the ghosts of its past. It disapproved of the introduction of property restitution legislation in the Czech Republic. ČSSD's position on property restitution switched from disapproval (stronger than KSČM's) to endorsement between 1992 and 1996. The Czech Socialist Party participated in the 1992 elections as part of the Liberal Social Union coalition (LSU). LSU endorsed the introduction of a market economy even more strongly than did either the KSČM or the ČSSD; $5 \%$ of their program was dedicated to lauding the virtues of the market economy. The Socialists' advocated European integration; they paid more attention to the issue in their programs than the Communists but not as much as the Social Democrats $(2.67 \%$ of the LSU program focused on EU membership). The Socialists did not take a stand on property restitution in their 1992 program. 
Table 2. Left-Right Self-Placement of Party Supporters of KSČM and ČSSD (\%)

\begin{tabular}{llllll}
\hline Parties & $\mathbf{1}$ & $\mathbf{2}$ & $\mathbf{3}$ & $\mathbf{4}$ & $\mathbf{5}$ \\
\hline ČSSD & 4 & 32 & 60 & 4 & - \\
KSČM & 40 & 46 & 12 & 1 & 1 \\
\hline
\end{tabular}

1-Clear left 2-Somewhat left 3-Center 4-Somewhat right 5 -Clear right

Source: Klíma, M. (1998) 'The Party System in the Czech Republic’, in Hofferbert, R. (ed) (1998).

Table 2 shows that KSČM supporters held more radical (left) economic views than ČSSD supporters. As much as we may doubt self-placement numbers, the data displayed in the table shows that most ČSSD supporters perceived themselves as moderate, whereas most KSČM supporters thought of themselves as people with left or somewhat left leanings. The data is consistent with most qualitative assessments of the political preferences of the KSČM and ČSSD voters (Grzymała-Busse, 2002; Hanley, 2002; Kostelecký, 2002).

4.5 Assessing the Performance and Adaptation Strategies of the Communist Party of Bohemia and Moravia and the Czech Social Democratic Party

Due to the stringent lustration laws in the Czech Republic, political parties cannot recruit candidates who have collaborated with the repressive regime of the communist state. Even though the orthodox Communist Party members insisted on keeping 'communist' in the label, the party leadership found another trick to mask its traditional communist roots in the 1992 elections and attract voters without affronting the members. It formed a pseudo coalition with a tiny political formation - the Democratic Left. (Note 28) The two parties formed the Left Bloc and competed under that name in the National Council elections. The Democratic Left, however, played a minuscule role in the coalition and gave the Communists free reign in the candidate selection process.

After the Czech Social Democrats severed their ties with the Czechoslovak Communist Party, its electoral performance dramatically improved. The party had barely crossed the $4 \%$ threshold in the 1992 elections, but in 1996 its share of the national vote nearly quadrupled and it became the second largest party in both legislative chambers. The Communists lost $30 \%$ of their national vote, partly due to the split of Czechoslovakia, and trailed far behind the Social Democrats.

Based on an analysis of the 1992 and 1996 vote, I found that though quite a few voters cast a preference vote in both parliamentary elections, their votes do not affect the final party ranks of the individual candidates. In the 1992 elections, for example, only two of the Communist candidates won seats with the help of their preference votes. Assuming a closed-list proportional representation system (and assuming that voters would have voted the same way), these two candidates would not have been elected. Obviously parties would be interested in nominating candidates who will boost their electoral performance. The results were quite similar in the Czech Social Democratic Party - only one candidate would not have won a legislative seat under a closed-list system (a candidate in $8^{\text {th }}$ electoral district). In the 1996 parliamentary election, there was an increase in the proportion of KSČM and ČSSD voters who cast personal votes. The results of the Czech electoral system, ceteris paribus, are similar to the results one would expect to observe under a closed-list system. (Note 29)

Despite its humble start, in which it won merely $6 \%$ of the national vote, the Czech Social Democratic Party quickly gained momentum and credibly set itself apart from the orthodox communist elite now in command of KSČM. The Social Democrats were able to attract even some of the most progressive politicians whose ideas of party reform had been rejected by KSČM politicians steeped in traditional communist teachings. Former party functionaries who had occupied positions in higher rungs in the communist party hierarchy found it hard to find a political haven outside of the communist successor party.

Analysis of the 1996 KSČM and ČSSD vote shows that though the Social Democrats did not steal too many votes from the communists, they did capitalize on the communists' inability to transform into a moderate leftist party (Novák, 2003). The communists could count on the vote of a loyal group of supporters who regularly turned out at elections. The surge of the Social Democrats' electoral performance could be attributed mostly to the votes the party received from the nationalist Sdružení pro republiku - Republikánská strana Československa (SPR-RSC or Association for the Republic - Republican Party of Czechoslovakia). In 1996 ČSSD won the support of 75.3\% of the people who had voted for it in 1992 (Novák, 2003).

Political geographer Petr Kostelecký discovered an interesting pattern in the ČSSD vote in the 1996 elections. There was a significant change in the geographic distribution of support for the party between the 1992 and 1996 
elections. He attributes this change partly to moving the party's popular leader Miloš Zeman from the list in the Jihočeský region (where he won $25.57 \%$ of the personal votes) to the Severomoravský list (where he won $17.55 \%$ of the personal votes). Thus, while most of the party's votes had come from southern Bohemia in 1992, in 1996 most votes came from northern Moravia. The correlation between Zeman's move from one list to the other and the electoral performance of the party is positive and significant at the 0.01 level after controlling for socio-economic factors such as regional unemployment and income level. The Social Democrats' vote quadrupled in northern Moravia as a result of the transfer of a highly popular list leader to that regional list. (Note 30) While this is not full-proof evidence in support of my hypothesis that people care about personalities in candidate-centered systems, it is certainly a good initial piece of evidence. The party probably strategically nominated Zeman to run in a district where it did not enjoy strong support because he enjoyed widespread popularity. Had he not been a highly respected figure in northern Moravia, he and the party would not have taken the risk of not getting their party leader elected.

Zeman had a solid dissident record dating back to the Prague Spring. He did not apply for Communist Party membership until reformist leader Alexander Dubček took over the Politburo in 1968. Zeman built the reputation of an unforgiving critic of the communist hardliners, which cut his political ambitions short soon after the Soviet crackdown on the Czechoslovak dissident movement. He was expelled from the party, but that was only the beginning of a conflict-ridden relationship with the party bigwigs. He took every opportunity to lambaste the government and lost his job twice. After the Communists left power Zeman served as chairman of the Social Democratic Party and as Prime Minister following the electoral victory of the Social Democrats in 1998. He never failed to sow controversy with his blunt statements and developed an uneasy relationship with journalists. The media retaliated by frequently catching him off guard and publishing photos of him smoking, drinking his favorite liqueur or snoozing in parliament. If anything, these images earned him the reputation of a maverick, yet charismatic, politician who never hesitated to speak his mind. None of the leaders of the Communist Party of Bohemia and Moravia matched Zeman's political record. In spite of people's skepticism, he even managed to hold a minority government together for four years because he commanded the respect and trust of the opposition leadership of the centre-right Civic Democratic Party.

KSČM lost some votes to ČSSD in the 1996 parliamentary elections. The losses were registered in districts with high unemployment and most likely these votes went to ČSSD (Kostelecký, 2003). There is no significant correlation between the electoral performance of the right-wing opposition parties and the level of unemployment across the eight electoral districts. The failure of reformers in the KSČM to improve the party image and moderate its ideology essentially allowed the Social Democrats to lay claim on the social democratic vote. While in Bulgaria, Hungary, and Lithuania among other countries, the main successor parties captured the social democratic vote, in the Czech Republic the social democrats became the loyal constituency of the historic Czech Social Democratic Party.

In spite of catering exclusively to its loyal supporters, most of whom are diehard communists, KSČM has been able to win enough votes in each parliamentary election between 1990 and 2006. The electoral results for the ex-communists and the Social Democrats are displayed in Table 3.

Table 3. Electoral Performance of KSČM and ČSSD (1990-2006) [\% Popular Vote \& Rank]

\begin{tabular}{|c|c|c|c|c|c|c|c|c|c|c|c|c|}
\hline Party & 1990 & & 1992 & & 1996 & & 1998 & & 2002 & & 2006 & \\
\hline KSČM & 13.2 & $2^{\text {nd }}$ & 14.1 & $2^{\text {nd }}$ & 10.3 & $3^{\text {rd }}$ & 11 & $3^{\text {rd }}$ & 18.51 & $3^{\text {rd }}$ & 12.81 & $3^{\text {rd }}$ \\
\hline ČSSD & 4 & $5^{\text {th }}$ & 6.5 & $3^{\text {rd }}$ & 26.4 & $2^{\text {nd }}$ & 32.2 & $1^{\mathrm{st}}$ & 30.2 & $1^{\mathrm{st}}$ & 32.32 & $2^{\text {nd }}$ \\
\hline
\end{tabular}

Source: Czech Statistical Office elections server, http://www.volby.cz

Although KSČM attracted enough votes to come in $2^{\text {nd }}$ (in the first two elections) or $3^{\text {rd }}$ (in the next three elections), it has never participated in a governing coalition. Most political parties, including the Social Democrats, will not consider it a suitable partner for an electoral or cabinet coalition. The party does, however, hold enough parliamentary seats, which has guaranteed it blackmail potential. ČSSD was the formateur of two coalition governments - in 1998 and 2002 - and has had to rely on votes of KSČM parliamentarians to pass its legislative initiatives. If we were to assess KSČM's electoral success in mathematical terms, it is certainly not the most successful party in the Czech system. It has, however, exerted much more political influence than most people had anticipated it would. The ex-communists' political prognosis was not very sanguine in 1993, when 
the orthodox wing took over the party leadership and chose not to reinvent the party's image. While KSČM has not been as successful as any of the reformed communist parties in Eastern and Central Europe, it is the most successful orthodox ex-communist party in the region. No other orthodox party - the Hungarian Workers', the Bulgarian Communists or the Lithuanian Socialists - has matched its success. In fact, none of the other orthodox parties mentioned overcame the minimal electoral thresholds of $4-5 \%$ in their systems.

\section{Conclusions}

In spite of retaining its orthodox communist party program, the Czech ex-communists have been able to attract sufficient voter support to win parliamentary seats. The party has traditionally ranked second and third in terms of the proportion of the national parliamentary vote it has secured between 1990 and 2006. Its electoral performance makes it the only orthodox communist party in ex-communist Europe to maintain significant electoral support. To date, scholars have underestimated the adaptive capacity of KSČM because they tend to compare it to ex-communist parties that have taken a social democratic turn rather than parties that have retained their orthodox communist platform. My explanation of the programmatic trajectory of the Czech ex-communists includes two factors. First, the leadership squabbles that took place inside the party ranks were resolved in favor of the orthodox party wing. KSČM had ample opportunity to initiate and carry out the same programmatic changes that the Hungarian Socialists did after their electoral failure in the founding elections. Second, KSČM leaders did pursue an optimal adaptation strategy consistent with their electoral goals. After the leadership dispute over the party's programmatic orientation was resolved, its main electoral goal was to cater to the vote to the most loyal party supporters with an orthodox communist ideology. The party leaders delegated nomination powers to the local party branches and placed important decisions about legislative candidate selection in the hands of party members and activists. The social democratic vote then was up for grabs and the historic Czech Social Democratic Party emerged as the political party that would attract most of that social democratic vote.

\section{References}

Ágh, A. (1995). 'Partial consolidation of the East-Central European Parties: the case of the Hungarian Socialist Party', Party Politics, 1(4), October.

Birch, S. et al. (2002). Embodying Democracy: Electoral System in Post-Communist Europe (Houndmills, Basingstoke, England, Palgrave Macmillan).

Brokl, L., \& Mansfeldová Z. (1998). 'Czech Republic', European Journal of Political Research, 34, 3-4, December. http://dx.doi.org/10.1023/A:1007020028556

Crampton, R. J. (2003). Eastern Europe in the Twentieth Century and After (London and New York, Routledge).

Epstein, L. (1980). Political Parties in Western Democracies (New Brunswick, N.J., Transaction Books).

Fawn, R. (2000). The Czech Republic: A Nation of Velvet (Amsterdam, Harwood Academic Publishers).

Fiala, P., \& Strmiska, M. (eds) (2005). Viceúrovňové vládnutí: teorie, př́stupy, metody (Brno, CDK).

Filip, J. (2003). 'Electoral Legislation in the Years 1992 to 1996', in Mansfeldová Z., (ed) (2003).

Grzymała-Busse, A. (2002). Redeeming the Communist Past: The Regeneration of Communist Parties in East Central Europe (Cambridge, Cambridge University Press). http://dx.doi.org/10.1017/CBO9780511613388

Hanley, E. et al. (1998). The Making of Post-Communist Elites in Eastern Europe, Working Paper 4, (Prague, Institute of Sociology).

Harmel, R., \& Janda, K. (1982). Parties and Their Environments: Limits to Reform? (New York, Longman).

Harmel, R., \& Janda, K. (1994). 'An Integrated Theory of Party Goals and Party Change', Journal of Theoretical Politics, 6(3), July. http://dx.doi.org/10.1177/0951692894006003001

Hermens, F. (1972) Democracy or Anarchy? (New York, Johnson Reprint).

Hofferbert, R. (ed) (1998). Political Studies, 46, 3, February.

Janda, K. (1983). 'Cross-national Measures of Party Organization and Organizational Theory' European Journal of Political Research, 11, 3, September. http://dx.doi.org/10.1111/j.1475-6765.1983.tb00065.x

Kabele, J. et al. (Eds.) (2004). Rozvoj české společnosti v Evropské unii I - Sociologie, prognostika a správa (Praha, Matfyzpress).

Kitschelt, H. et al. (1999). Post-communist Party Systems: Competition, Representation, and Inter-party cooperation (Cambridge, Cambridge University Press). 
Klíma, M. (1998). 'The Party System in the Czech Republic', in Hofferbert, R. (ed) (1998).

Klingemann, H. et al. (Eds.) (2006). Mapping Policy Preferences II: Estimates for Parties, Electors, and Governments in Eastern Europe, European Union, and OECD 1990-2003 (Oxford, Oxford University Press).

Kopecký, P. (2001). Parliaments in the Czech and Slovak Republics Party Competition and Parliamentary Institutionalization (Surrey, Ashgate and Gower).

Kostelecký, T. (2002). Political Parties after Communism: Developments in East-Central Europe (Baltimore and London, Johns Hopkins University Press).

Laffin, M., Shaw, E., \& Taylor, G. (2007). 'The New Sub-National Politics of the British Labour Party', Party Politics, 13(1), January. http://dx.doi.org/10.1177/1354068806071265

Linek, L., \& Rakušanová, P. (2005). 'Why Czech Parliamentary Party Groups Vote Less Unitedly: The Role of Frequent Voting and Big Majorities in Passing Bills', Czech Sociological Review, 41, 3.

Linek, L. (2004). ‘České politické strany a jejich členové k postupné proměně charakteru členství', in Kabele, J. et al. (Eds.) (2004).

Linek, L. (2009). 'Czech Republic', European Journal of Political Research 48, 7-8, December. http://dx.doi.org/10.1111/j.1475-6765.2009.01879.x

Mansfeldová Z., (Ed.) (2003). Czech Republic: The First Elections in the New Republic, 1992-1996 (Berlin, Edition Sigma).

Miller, W. L., White, S., \& Heywood, P. (1998). Values and Political Change in Post-communist Europe (London, Macmillan). http://dx.doi.org/10.1057/9780230377448

Nalepa, M. (2010). Skeletons in the Closet (Cambridge, Cambridge University Press).

Novák, M. (2003). 'The Czech Party System’ in Mansfeldová, Z. (ed) (2003).

Pšeja, P. (2005). 'Některé otázky výzkumu politických stran České republiky’, in Fiala, P. \& Strmiska, M. (eds) (2005).

Sartori, G. (2005). Parties and Party Systems: A Framework for Analysis (Oxford, European Consortium for Political Research).

Seidlová, A. (2001). 'Výzkum poslanců a senátorů Parlamentu ČR. Technické informace o výzkumu', Sociologický časopis, 37, 3.

Šimíček, V. (2003). 'Nomination of candidates by political parties for parliamentary elections; funding of political parties', in Mansfeldová, Z. (ed) (2003).

Suda, Z. (1980). Zealots and Rebels: A History of the Ruling Communist Party of Czechoslovakia (Stanford, CA, Hoover Institution Press).

Van Biezen, I. (2000). 'On the Internal Balance of Party Power: Party Organizations in New Democracies', Party Politics, 6(4), October. http://dx.doi.org/10.1177/1354068800006004001

Waller, M. (1995). 'Adaptation of the former Communist Parties of East-Central Europe: a case of Social-Democratization', Party Politics, 1(4), October. http://dx.doi.org/10.1177/1354068895001004003

\section{Notes}

Note 1. A moral vote is based on voters' moral response to candidates' possible complicity with the communist authorities. Voters who support the ancien régime are more likely to vote for a candidate (or party) who had links with this regime than those who oppose it. However, support for a communist candidate does not necessarily imply support for the ancien régime.

Note 2. Politicians in some countries responded to pressures to initiate lustration procedures (Poland), whereas leaders in other countries restricted access to classified documents for a limited time (Bulgaria). See Nalepa (2010) for an in-depth discussion of these deliberations and legal arrangements.

Note 3. Some scholars may find the assumption that voters prefer democracy to authoritarianism strong. Some voters do indeed associate authoritarianism with stability, employment, and security and will gladly trade a democratic for authoritarian government in the short run albeit they are aware of its negative long-term consequences. 
Note 4. Yet another caveat one ought to consider is the political background of the selectors themselves. The authoritarian links of the selectors (i.e. party leaders at the local or national level) will probably influence their nomination decisions and affect the probability of selecting candidates with authoritarian links. If the assumption that voters' decisions are based on moral grounds is correct, however, choosing candidates with authoritarian links is not an equilibrium strategy, for successor parties may risk electoral failure.

Note 5. The ČSSD party convention, for example, accepted the Bohumín Declaration in 1995, which prohibits cooperation with KSČM at the national level (Linek, 2009).

Note 6. The formation of such umbrella associations between the Communist Party and its rivals was common across Eastern and Central Europe. These organizations helped communist parties provide a semblance of democracy by allowing some competition within their ranks.

Note 7. The party's original name was Česká strana národně sociální (Czech National Socialist Party).

Note 8. Some Communist Party parliamentarians broke away and joined the Social Democrats in the 1990s (Fawn, 2000).

Note 9. Civic Forum was one of the two main opposition movements, along with Public Against Violence in Slovakia, which competed in the first democratic elections (1990).

Note 10. For a detailed account of the evolution of the Czech electoral system, see 'The Czech and Slovak Republics: the Surprising Resilience of Proportional Representation' in Birch et al. (2002).

Note 11. Act No. 54/1990 Collection on Elections to the Czech National Council in (Mansfeldová, 2003).

Note 12. Act No. 54/1990 Collection on Elections to the Czech National Council in (Mansfeldová, 2003).

Note 13. Voters' behavior at election time affects the degree to which the system is party-centered as opposed to candidate-centered. The more voters use their preference votes, the more influential their input in determining the final list order. The system could be party-centered for one political party and candidate-centered for another depending on the voters who cast a ballot for a given party. Thus, the incentives for decentralizing the candidate selection process vary from party to party and from district to district for the same party.

Note 14. Pre-election surveys in the Czech Republic in 1996 revealed that voters consider party ideology, program, and leaders' qualities the most important factors that influenced their choice of a party list (Seidlová, 2003). The surveys were performed by the Czech polling agency IVVM in April 1996, two months before the elections.

Note 15. There are at least two major reasons for the existence of thresholds that define the weight of voters' preferences on final list rankings. First, it prevents small groups of party supporters from re-arranging the entire list. Italy's pre-1993 electoral system had no thresholds limiting the weight of personal votes; it could take a single voter's preferences over candidates to re-rank the entire party list. Second, the initial rankings also give party leaders (and other groups within the party) at least some control over the fate, and hence discipline, of list candidates.

Note 16. There were also proposals to introduce an alternative voting system as in Australia and a plurality system as in the United Kingdom, but in the end a runoff system was approved. There were never any discussions of introducing a proportional system to decide the outcome of senate races.

Note 17. This prediction hinges on two factors - the threshold for winning a seat in the upper and lower chamber and the value/prestige associated with a seat in the two chambers. There will be more candidates for a position that is considered more valuable or prestigious. At the same time some candidates may choose to run for a less prestigious elected post just because it is easier to win. These personal calculations will depend on numerous factors such as ballot access for a seat in the two chambers, likelihood of winning, value of the position, etc.

Note 18. Van Biezen (2003) documents that the selection procedures for candidates for municipal office are decentralized across parties. The central party offices do not generally interfere with the decisions of local offices even in the most centralized parties.

Note 19. There were proposals for internal democratization of KSČ in the late 1960s (Crampton, 2003). Those proposals, however, were put on the table by reformist leaders led by Alexander Dubček - the famous Prague Spring figure. These decentralization efforts never bore fruit because of the Soviet crackdown in 1969.

Note 20. The party leaders paid lip service to internal party democracy on programmatic issues too. Since 1993, under the leadership of Miroslav Grebeníček, 'party programmatic documents were simply distributed to the local organizations after they had already been approved and formalized' (Grzymała-Busse, 2002). 
Note 21. Most of these active party members were elderly people who had joined the Czechoslovak Communist Party in the 1945-48 period. Their idea about communism was different from that of the $18.2 \%$ members who had joined the party during the so called 'normalisation' (1971-80), a period notorious for brutal political repression (Hanley, 2002). It seems that it was not very provident of the KSČM to please this small group of people who would not be voting for too long.

Note 22. Perhaps one of the reasons for the decentralization was the intention to maintain party cohesion. The party was quite heterogeneous in composition. It even became home to the reform Communist leader - Jiří Svoboda - who decided to resign as party chief after facing aggressive opposition to his reform package. In its formative years, the party accepted exiled dissidents, splinter groups from the opposition movement, and a small number of reform communists (Novák, 2003).

Note 23. I compiled a list of all candidates to the Czechoslovak Parliament and Senate in 1990 and 1992, and all candidates to the Czech Parliament and Senate in 1996 from the official webpage of the Czech Electoral Commission, available via http://www.volby.cz/index.htm, accessed March 2011. I cross-referenced the names of all Politburo and Central Committee members listed in the 1989 'East European Leadership List' of Radio Free Europe/Radio Liberty, available via http://www.osaarchivum.org/files/holdings/300/8/3/text/120-3-223.shtml, accessed March 2011.

Note 24. Czechoslovak Social Democracy was the original name of the Czech Social Democratic Party before the separation of the Czech Republic and Slovakia.

Note 25. He won only 627 votes. KSČM was able to win only two seats in the Senate in 1996.

Note 26. Blanton, T. (ed) (1999) 'The Revolutions of 1989: New Documents from Soviet/East Europe Archives Reveal Why There Was No Crackdown', 5 November 1999, available via http://www.gwu.edu/ nsarchiv/news/19991105/, accessed March 2011.

Note 27. The Lustration Act of October 1991 required that candidates for elected post present a negative 'lustration certificate', 'proving that from February 25, 1948 to November 17, 1989 the applicant had never been included in the State Security file or registered in the State Security documents as a resident, agent, informer or ideological collaborator of the State Security, that s/he had not been a secretary of a body of the Czech Communist Party of the Communist Party of Slovakia at a regional level or higher, a member of the People's Militia, a member of an action committee of the National Union, a student of the University of F. E. Dzerzhinsky of the Council of Ministers of the USSR, the University of the Ministry of Interior of the USSR, the Political College of the Ministry of the USSR or a research fellow at any of the above educational institutions', Seidlová (2003). The Lustration Act encompassed many former communist leaders and functionaries and people responsible for political repression during communism. If compliance with the law were complete, it would have cut short the career ambitions of nearly any candidate with communist links. Political parties had to present negative 'lustration certificates' for their candidate slate, but there was no monitoring agency to ensure compliance with the Lustration Law.

Note 29. The Democratic Left should not be confused with the Party of the Democratic Left, which had branches nationwide, and became the main Slovak communist successor after the Velvet Divorce.

Note 30. The results are similar to the expected results in a closed-list system for the two parties analyzed here. I have not studied whether similar results obtain for the other political parties; Filip (2003) reports that in the 1990 National Council elections there were ' 34 cases in which a candidate (generally a well-known person from the world of arts) moved up to the head of the list'. The geographic distribution of votes of Civic Democratic Alliance also changed as the party moved key leaders from one district to another. Kostelecký (2002) has found that 'the party's greatest loss [in 1996] was in central Bohemia, and its greatest gain was in southern Moravia. The changes were again due to the effects of the popularity of the parties' [sic] celebrities. The popularity of the party chairman Kalvoda declined as he turned from successful negotiator with Slovaks to not very successful Minister of Justice in Klaus's Czech Government. Thus, Kalvoda's move from the top of the party list in the central Bohemian electoral region to the leading position on the ODA list in Prague did not add any votes to the party in Prague and resulted in a net loss in most central Bohemian districts'. 